\title{
Spectral characterization of mangrove leaves in the Brazilian Amazonian Coast: Turiaçu Bay, Maranhão State
}

\author{
FLÁVIA REBELO-MOCHEL ${ }^{1}$ and FLÁVIO J. PONZONI ${ }^{2}$ \\ ${ }^{1}$ Departamento de Oceanografia e Limnologia, Universidade Federal do Maranhão, Campus Universitário, Bacanga \\ 65080-240 São Luís, MA, Brasil \\ ${ }^{2}$ Instituto Nacional de Pesquisas Espaciais, Divisão de Sensoriamento Remoto, Av. dos Astronautas, 1758 \\ 12227-010 São José dos Campos, SP, Brasil \\ Manuscript received on February 2, 2006; accepted for publication on December 12, 2006; \\ presented by ALCIDES N. SIAL
}

\begin{abstract}
Mangrove communities are tropical systems which have fewer species than tropical forests, especially in Latin America and display a single architecture, usually lacking the various strata commonly found in other forest ecosystems. The identification of mangrove communities by orbital data is not a difficult task but the most interesting challenge is to identify themselves by the dominant species. The first step toward that floristic identification is the spectral characterization of detached leaves. Leaves from four species of mangrove trees were spectrally characterized considering the Directional Hemispherical Reflectance Factor (DHRF) determined through radiometric measurements using an integrating sphere LICOR 1800 attached to a spectroradiometer SPECTRON SE-590. In the visible bands $(0.45-0.69 \mu \mathrm{m})$ the button-shaped mangrove Conocarpus erectus was brighter and the red mangrove Rhizophora mangle was darker than the other two species which shows very close DHRF values. Otherwise the black mangrove Avicennia germinans and the white mangrove Laguncularia racemosa can be distinguished from one another in the Near Infra Red (NIR) region (0.76-0.90 $\mu \mathrm{m}$ and in this region of the spectrum the DHRF of C. erectus and $R$. mangle become very close.
\end{abstract}

Key words: leaf reflectance, mangroves, spectral characterization of leaves.

\section{INTRODUCTION}

Mangroves are valuable coastal systems (Cintrón and Schaeffer-Novelli 1992, Robertson 1992, Lacerda et al. 1993). They are known to protect the environment against erosion and flooding, to process pollutants and waste discharge contaminated with heavy metals (Silva et al. 1990), to export organic matter to estuarine areas and thereby increasing fisheries yield (Cintrón and Schaeffer-Novelli 1983, Twilley 1985), as to shelter threatened species (Rebelo-Mochel et al. 1991, RebeloMochel 1993).

The Amazonian coast, comprised by the Brazilian states of Maranhão, Pará and Amapá, contains the largest

Correspondence to: Flávio Jorge Ponzoni

E-mail: flavio@dsr.inpe.br continuous mangrove system in the world, measuring $8,900 \mathrm{~km}^{2}$ (Kjerfve et al. 2002). The state of Maranhão is located in the north coast of Brazil and it contains about 750,000 ha of mangroves (Sant'Anna and Whately 1981, Kjerfve and Lacerda 1993). The macrotidal coast of Maranhão contains 500,000 ha of these mangroves, more than $30 \%$ of the total for all Brazil. Biomass may reach 280 ton/ha or more, with trees taller than $40 \mathrm{~m}$ in some places (Cintrón and Schaeffer-Novelli 1983, Kjerfve and Lacerda 1993, Rebelo-Mochel 1995). Mangrove species in this region are three species of red mangroves Rhizophora mangle, Rhizophora racemosa, Rhizophora harrisonii, two species of black mangroves Avicennia germinans, Avicennia schaueriana, the white mangrove Laguncularia racemosa and the buttom-shaped man- 
grove Conocarpus erectus (Santos 1986, Rebelo-Mochel et al. 1991).

The west coast of Maranhão is sharply cut by rivers, streams and tidal channels filled with clay and silt which foster the development of mangroves. The mouth of Turiaçu River is one of the largest entrances of the region with a surface area of $900 \mathrm{~km}^{2}$. Satellite remote sensing might be the most cost-effective technique for evaluating mangrove distribution and biomass. Long and Skewes (1996) described a technique using Thematic Mapper (TM) satellite images to inventory Australian mangroves. The use of Multispectral Scanner (MSS) and TM satellite images to identify mangrove areas along the Brazil coast has previously been accomplished by Herz and Jaskow (1985), Herz (1985), Pires (1986), Pires and Herz (1987, 1988) and Herz (1991). Indeed, delimitation of mangrove occurrences using multispectral data is not a hard task considering the spectral contrast between this morphological unit and other land cover types. The problem however is set when it is necessary to identify different mangrove types, especially species composition, due to the existence of mixed stands and the characteristics of coastal landforms. But the potential advantage in that identification procedure through remote sensing technology is the fact that there are few species on mangrove environments compared with other tropical rain forests. Indeed, the Atlantic coast of Americas has 3 species of Rhizophora, 2 of Avicennia, 1 of Conocarpus and 1 of Laguncularia.

Some attempts have been made to describe mangrove communities by their spectral reflectance in the field. These techniques are generally expensive and laborious, but there are some aspects that become promising in mangrove studies. As mentioned above, mangrove communities have fewer species than tropical forests, especially in Latin America and display a single architecture, usually lacking the various strata commonly found in other forest ecosystems. Besides, mangroves grow in coastal plains with low relief and estuarine waters, forming extensive zones dominated by 1 or 2 species, with relative homogeneous physiography.

Considering leaves as the most important part of a plant in terms of its interaction with the electromagnetic radiation, the spectral reflectance of leaves has great influence on the canopy bidirectional reflectance. Thus, the spectral characterization of leaves can give information about the opportunities and constrains of the canopy identification. These facts reinforce our belief that in mangrove environment it would be possible to find a strong correlation between spectral reflectance of detached leaves and the spectral response of mangroves canopies measured by an orbital located sensor. One most important aspect to be considered here is related to the real possibility to spectrally characterize leaves of each mangrove species, in other words, if we can segregate mangrove species from their leaves reflectance spectra. The complete understanding of that aspect is the first step to be carried out toward the use of orbital data for discriminating mangrove species.

The main goal of this work is to characterize the reflectance of leaves of four mangrove species that occur in the State of Maranhão, Amazonian coast of Brazil, in order to distinguish them one from another. This spectral characterization can later help the inventory and description of mangroves communities in that region utilizing orbital data.

\section{MATERIALS AND METHODS}

\section{STUDY AREA}

Turiaçu Bay is located between latitudes $\mathrm{S} 1^{\circ} 20^{\prime}-1^{\circ} 45^{\prime}$ and longitudes $\mathrm{W} 45^{\circ} 10^{\prime}-45^{\circ} 20^{\prime}$ in the western coast of Maranhão State, northern Brazil (Fig. 1). The extension of the ecosystem, the presence of pure and mixed stands of mangrove species and the low human density and high pristine areas, make this region profitable for regional studies.

Turiaçu Bay has a surface area of $900 \mathrm{~km}^{2}$ and semidiurnal tides range up to $8 \mathrm{~m}$ (Department of Navigation DHN). The annual precipitation averages 2,000 $\mathrm{mm}$ with maximum of $500 \mathrm{~mm}$ in March and minimum of $14 \mathrm{~mm}$ in September-November. Mangrove vegetation covers the borders of the bay, mounting tidal channels (igarapés) and streams, reaching inland as far as $100 \mathrm{~km}$ up the Turiaçu River. The mangrove species that occur in this region are Rhizophora mangle, Avicennia germinans, Laguncularia racemosa and Conocarpus erectus, facing estuarine fringes, basins, hypersaline environments, riverine channels and freshwater wetlands (várzeas).

The field work was performed in Bacuri municipality, right side of Turiaçu Bay, during July 1997. There 


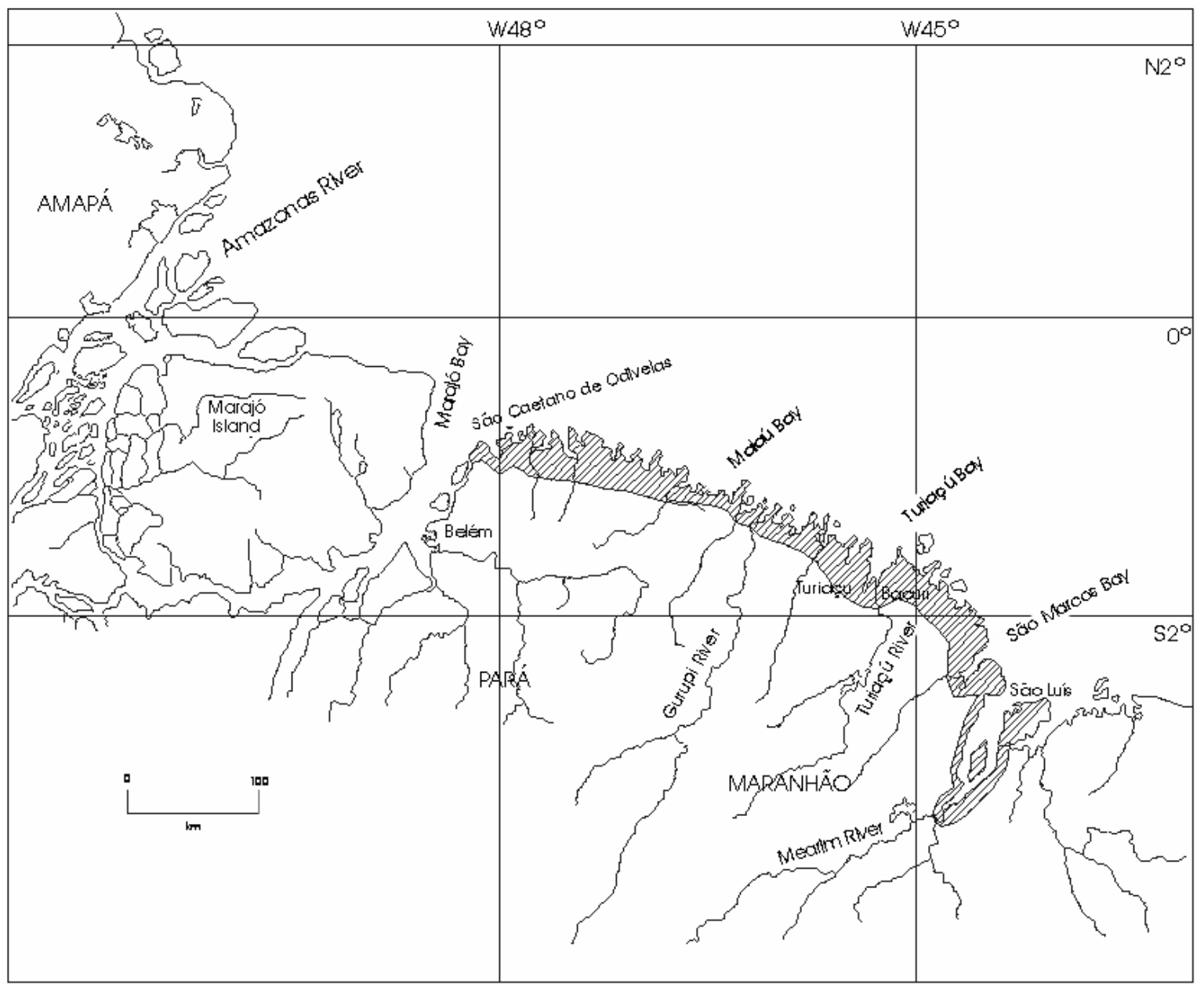

\section{Mangrove}

Fig. 1 - Localization of the Turiaçú bay.

were selected 26 sample plots over 4 mangrove environments: fringe, basin, riverine and hypersaline habitats.

\section{Leaf SAmpling and Structural Data}

The data collection was carried out inside plots of about $30 \mathrm{~m} \times 30 \mathrm{~m}$ in each of the 26 selected sample plots. Leaves on the top of the canopy were detached from arbitrarily selected trees by climbing and cutting the upper branch exposed to the sun, according to SchaefferNovelli and Cintrón (1986). There were collected about 42 leaves from each mangrove species that were find in each sample plot. The leaves were stocked in plastic bags and carried in ice boxes according to Sousa et al. (1996). All the reflectance measurements were performed 8 hours after leaves were detached since Ponzoni et al. (1997) didn't find any significant changes in the leaf reflectance measurements up to 10 hours after leaf detaching.

Structural data comprised tree height measured with a Ranging TLR 75 Telemeter and the diameter at the breast height with a calibrated ribbon, for all the trees over $2.5 \mathrm{~cm}$ in diameter as stated in Schaeffer-Novelli and Cintrón (1986). All the 26 sites were referenced with Scout GPS Trimble Navigation with an error of less than $90 \mathrm{~m}$ in the field.

Green leaves were collected and taken to the Labo- 
ratory of Botany of the Universidade de Taubate where their internal structures were examined taking into account the expected differences between species.

\section{Radiometric Measurements}

Radiometric measurements were performed with an integrating sphere LICOR 1800 attached to a spectroradiometer SPECTRON SE-590 that runs from $0.4 \mu \mathrm{m}$ to $1.1 \mu \mathrm{m}$, with $0.03 \mu \mathrm{m}$ of spectral resolution.

As the minimal number of leaves necessary to guarantee confidence to the statistical tests was not known in the beginning of the field work, Directional Hemispherical Radiance was measured for each of 42 detached leaves from each mangrove species in all the 26 sample plots by placing the addaxial (upper) surface of the leaf in the integrating sphere. After each group of 10 leaves, the reference panel $\left(\mathrm{BaSO}_{4}\right)$ inside the sphere was measured to calculate the Directional Hemispherical Reflectance Factors (DHRF). DHRFs were calculated considering the group of leaves closest (in time terms) to the spectra radiance of the reference panel.

The DHRF is given by the equation:

$$
\rho_{\lambda}=\frac{L_{\lambda \text { leaf }}}{L_{\lambda \text { pannel }}}
$$

where:

$$
\begin{aligned}
\rho_{\lambda}= & \text { directional hemispherical reflectance } \\
& \text { factor }(\mathrm{DHRF}) \\
L_{\lambda l e a f}= & \text { leaf directional hemispherical radiance; } \\
L_{\lambda \text { pannel }}= & \text { reference panel directional hemispherical } \\
& \text { radiance }\left(\mathrm{Ba} \mathrm{SO}_{4}\right) .
\end{aligned}
$$

The data were processed with the software "ESPECTRO" developed by the Radiometry Laboratory of the National Institute for Space Research (LARAD/ INPE). At this phase, there were determined 42 DHRFs spectra for each species that had been found in each of the 26 sample plots in the field. From these DHRF spectra it was calculated averages in four different spectral bands: blue $(0.45-0.52 \mu \mathrm{m})$, green $(0.52-0.60 \mu \mathrm{m})$, red (0.63-0.69 $\mu \mathrm{m})$ and near infrared $(0.76-0.90 \mu \mathrm{m})$. It was determined averages from each of those 42 repetitions, for each species, in each of these four spectral bands. The option of large spectral bands in spite of the fine SPECTRON SE-590 spectral resolution was based on Ponzoni and Gonçalves (1999) that compared the results achieved using large spectral bands and SPEC-
TRON SE-590 fine ones in DHRF of Eucalyptus saligna detached leaves. The authors found no differences using both spectral resolutions on an ANOVA statistical procedure. Thematic Mapper bands were adopted in this study with the aim of checking out possible modeling integrating radiometric data of leaves and Landsat/TM ones, which is the object of another study.

\section{STATistical ANALYSis}

To determine the minimum number of leaves necessary to set confidence to the spectral characterization, it was considered (for each spectral band) the equation:

$$
n=\frac{t^{2} \cdot C V^{2}}{d^{2}}
$$

where:

$n=$ minimum number of leaves;

$t=1.83$ (for 9 degrees of freedom and $10 \%$ of significance);

$d=$ minimum difference to be ratified (in this case, $10 \%$ );

$C V=$ coefficient of variation between DHRFs.

Ten spectra from all available ones for each species were randomly selected in order to determine the $n$ values for each band. The minimum number was identified as the higher $n$ value reached in this procedure, independent on the species.

Variance analysis (ANOVA) was applied for the averages of each spectral band to ratify if there were significant differences between the DHRFs for each species in each spectral band. The F value was considered at $10 \%$ of significance. After finding significant differences we tested the differences between the averages with Duncan's test also at $10 \%$ of significance.

\section{RESULTS AND DISCUSSION}

Considering the 26 sample plots, $C$. erectus was found in only one of them, L. racemosa in nine, A. germinans in nineteen and $R$. mangle in eighteen.

Results for the minimum number of leaves needed to set confidence to the statistical analysis were: 6 leaves for R. mangle; 8 for L. racemosa; and 33 for A. germinans. It was acquainted the spectra of 1,848 leaves (total) $\mathrm{r}$ considering the 4 mangrove species in the 26 sample plots. 


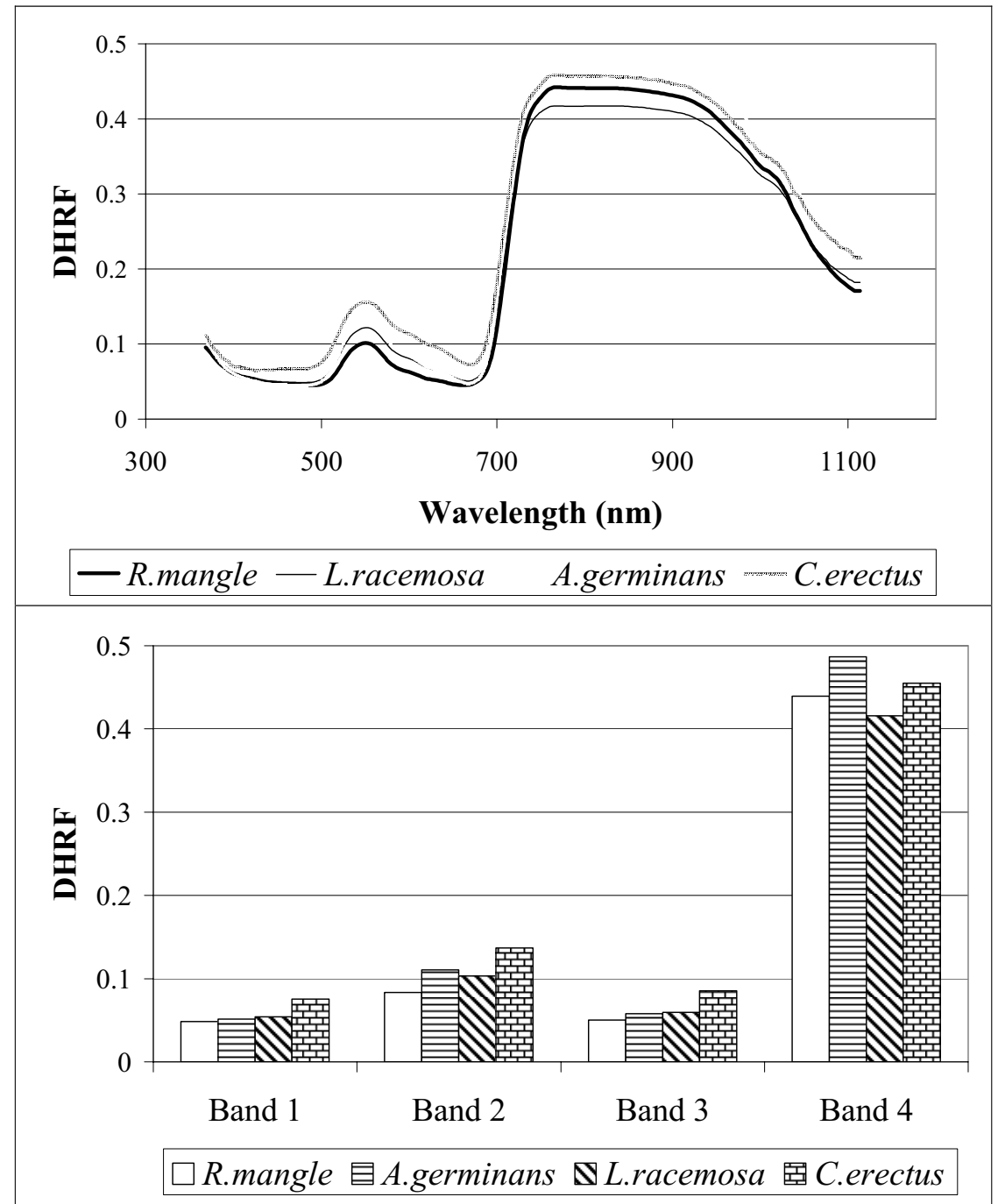

Fig. 2 - Complete HRF spectra and HRF for each spectral band of mangrove leaves.

The complete DHRF spectra and the DHRF for each spectral band of mangrove leaves are shown in Figure 2. The DHRFs presented on Figure 2 are average values calculated from all available spectra acquired from the 26 sample plots in the field. Some data were lost in data processing task, thus we decided to consider 39 leaf spectra in each of these sites to perform the statistical analysis for all species.

Observing Figure 2 it is possible to notice that in the visible bands (bands 1,2 and 3), C. erectus presented higher values of DHRF and $R$. mangle presented the lowest ones, while $A$. germinans and $L$. racemosa presented similar DHRF values themselves. That result could be an indicative that $C$. erectus leaves have lesser photosynthetic pigments than the other species leaves, but this was not confirmed in this paper. In the NIR region (band 4), A. germinans presented higher values of DHFR followed by $C$. erectus and $R$. mangle while $L$. racemosa presented the lowest ones, indicating that there are internal leaf structure differences between leaves of the four species themselves. Figure 3 shows a graphic representation of the averages of DHFR and their standard deviation in each spectral band for all species.

As expected, in bands 1 and 3 the DHFRs of all species were low due to photosynthetic pigments activity (Ponzoni 2001) with lower standard deviation values 
Band 1

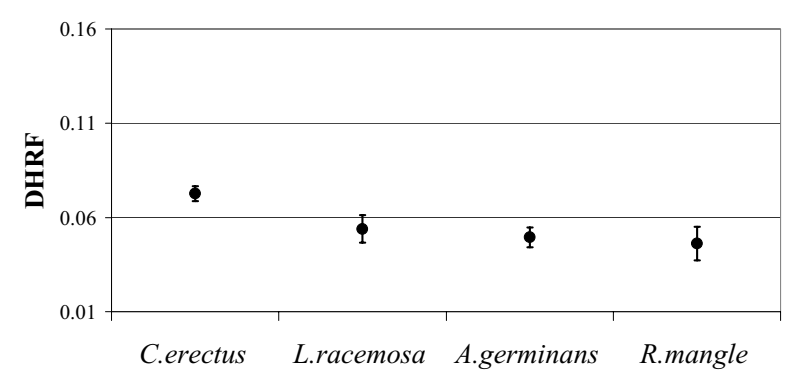

Band 3

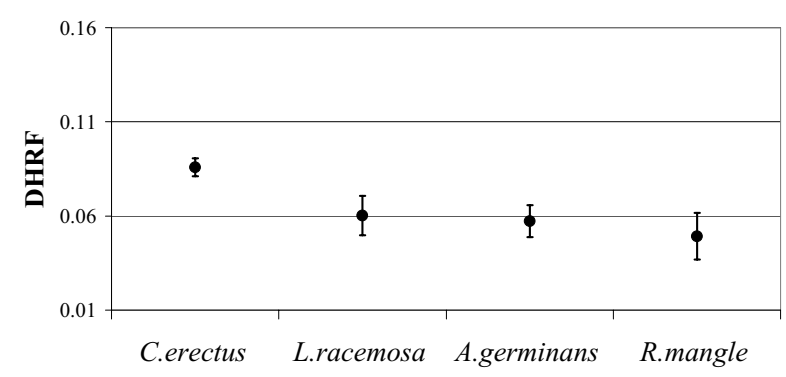

Band 2

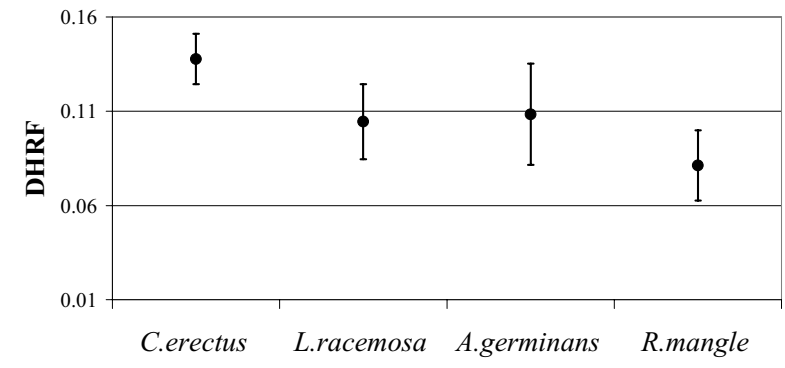

Band 4

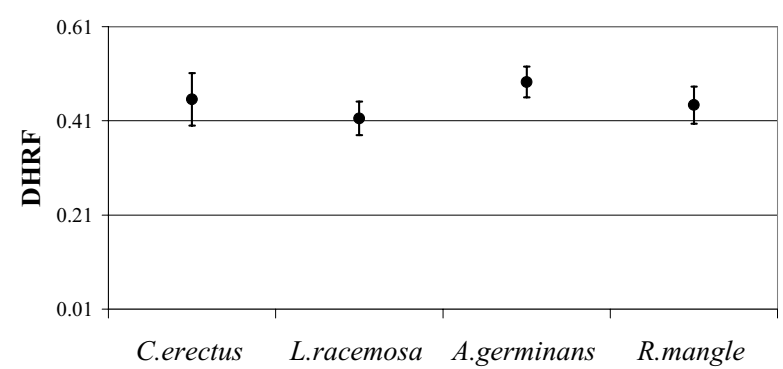

Fig. 3 - Averages and standard deviation of HFR in each spectral band for all species.

comparing with band 2 results. In band 4 both DHFR and standard deviation were higher than those observed in the visible bands.

A scatter plot composed by DHFR values from band 4 ( $y$ axe) and band 3 ( $x$ axe) is presented in Figure 4 in order to allow a complementary evaluation of the spectral differences between the leaves of the four species.

Considering the places of the DHFR values (four species) in the bi-dimensional scatter plot presented in Figure 4 one can observe that both L. germinans and C. erectus (even considering only one point for this last one) could be individualized from the others two species, besides being individualized themselves. The DHFR's dispersion for $R$. mangle was lower than those observed for the others, indicating higher homogeneity of DHFR values for this species.

The performance and results of the Analysis of Variance (ANOVA) are shown in Table I. All $\mathrm{F}$ values were considered significant at $10 \%$ of significance. It was performed Duncan's test to identify which averages of DHFR were different at the same level (10\%). Table
II presents the results of Duncan's test. All the species presented different DHFR values in band 1 . In bands 2 and 3, however, $C$. erectus and $R$. mangle remain with the higher and lower reflectances, while L. racemosa and A. germinans became closer and having no significant differences between their DHFRs. On the contrary, in the NIR region the DHFR values of $A$. germinans was higher and L. racemosa was lower than the other 2 species which spectra became closer. The spectral bands used in this study showed satisfactory results, finer bands, with more wavelengths seem to have little advantage for characterizing leaf spectral reflectance (Ramsey and Jensen 1996).

Radiant energy interacts with the leaf structure by absorption and by scattering (Gates et al. 1965). In the visible bands (1, 2 and 3) Cardoso and Ponzoni (1996) found similar spectral reflectance between 5 species of terrestrial shrubs, differences appearing in the NIR band 4 probably due to leaf mesophyll influence. Gausman (1974) demonstrated that compacted leaves had lower reflectance than leaves with porous mesophyll or with 


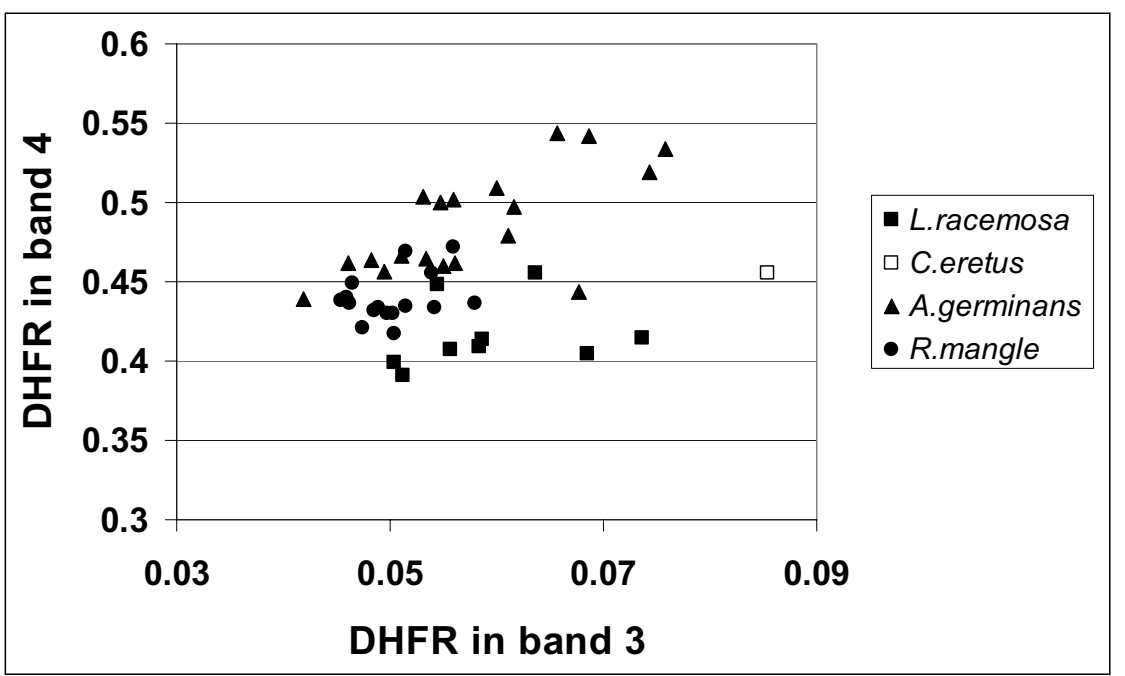

Fig. $4-$ DHFR band $4 \times$ DHFR band 3 scatter plot.

TABLE I

Results of ANOVA application on all species and spectral bands.

\begin{tabular}{c|c|c|c|c|c|c}
\hline Band 1 & $\begin{array}{c}\text { Square } \\
\text { sum }\end{array}$ & $\begin{array}{c}\text { Degrees } \\
\text { of freedom }\end{array}$ & $\begin{array}{c}\text { Mean } \\
\text { square }\end{array}$ & F & P-value & F-crit \\
\hline Species & 0.0164939 & 3 & 0.005498 & $121.94^{*}$ & $2.90 \mathrm{E}-40$ & 2.120 \\
\hline Residual & 0.0068529 & 152 & $4.508 \mathrm{E}-05$ & & & \\
\hline Total & 0.0233468 & 155 & & & & \\
\hline \hline Band 2 & $\begin{array}{c}\text { Square } \\
\text { sum }\end{array}$ & $\begin{array}{c}\text { Degrees } \\
\text { of freedom }\end{array}$ & $\begin{array}{c}\text { Mean } \\
\text { square }\end{array}$ & F & P-value & F-crit \\
\hline Species & 0.0627871 & 3 & 0.020929 & $49.681^{*}$ & $1.95 \mathrm{E}-22$ & 2.120 \\
\hline Residual & 0.0640332 & 152 & 0.0004213 & & & \\
\hline Total & 0.1268203 & 155 & & & & \\
\hline \hline Band 3 & $\begin{array}{c}\text { Square } \\
\text { sum }\end{array}$ & $\begin{array}{c}\text { Degrees } \\
\text { of freedom }\end{array}$ & $\begin{array}{c}\text { Mean } \\
\text { square }\end{array}$ & F & P-value & F-crit \\
\hline Species & 0.0294241 & 3 & 0.009808 & $106.966^{*}$ & $2.82 \mathrm{E}-37$ & 2.120 \\
\hline Residual & 0.0139374 & 152 & $9.169 \mathrm{E}-05$ & & & \\
\hline Total & 0.0433615 & 155 & & & & \\
\hline \hline Band 4 & $\begin{array}{c}\text { Square } \\
\text { sum }\end{array}$ & $\begin{array}{c}\text { Degrees } \\
\text { of freedom }\end{array}$ & $\begin{array}{c}\text { Mean } \\
\text { square }\end{array}$ & F & P-value & F-crit \\
\hline Species & 0.1216148 & 3 & 0.0405383 & $22.614^{*}$ & $3.68 \mathrm{E}-12$ & 2.120 \\
\hline Residual & 0.2724773 & 152 & 0.0017926 & & & \\
\hline Total & 0.3940922 & 155 & & & & \\
\hline & & & & & \\
\hline
\end{tabular}

*Significative at $10 \%$ level of significance.

many cell wall-air space interfaces. The anatomical analysis of the epidermis of mangrove leaves showed all the species are dorsiventral, or in other words with a marked dissimilarity between the upper and the lower halves, and a colorless tissue represented by a thick addaxial hypodermis (Tomlinson 1986). The white mangrove $L$. racemosa has the most compacted epidermis below the cuticular membrane of all the species examined. It has 
cuticular membrane and flanges strongly developed besides having a concentration of palisade layers below a very thin lacunal parenchyma. This is coherent with the low brightness explained by the lowest values of DHFR in the NIR bands (Figs. 3 and 4). The red mangrove $R$. mangle and the black mangrove $A$. schaueriana have a similar arrangement in the structure of the epidermis but Avicennia has far well developed lacunae in the parenchyma between the cuticular membrane and the palisade layers. This may explain the higher reflectance of this species in the NIR region. In this study we were not able to make anatomical analysis of $C$. erectus but Stace (1965) made a review of Combretaceae and reports that $C$. erectus has narrow-walled epidermal cells arranged in a very regular way. The weak arrangement of cells of $C$. erectus could be related to the high brightness of this species in the NIR region.

TABLE II

Duncan's test results for mangrove species, same letters indicate similar reflectance.

\begin{tabular}{l|c|c|c|c}
\hline & Band 1 & Band 2 & Band 3 & Band 4 \\
\hline C. erectus & $\mathrm{a}$ & $\mathrm{a}$ & $\mathrm{a}$ & $\mathrm{b}$ \\
\hline L. racemosa & $\mathrm{b}$ & $\mathrm{b}$ & $\mathrm{b}$ & $\mathrm{c}$ \\
\hline A. germinans & $\mathrm{c}$ & $\mathrm{b}$ & $\mathrm{b}$ & $\mathrm{a}$ \\
\hline R. mangle & $\mathrm{d}$ & $\mathrm{c}$ & $\mathrm{c}$ & $\mathrm{b}$ \\
\hline
\end{tabular}

In the visible bands the spectral response should be explained due to differences on the chemical components (differences), including photosynthetic pigments amount (Ponzoni 2001). As no chemical analysis were performed, it was impossible to compare chemical differences with radiometric ones. Gitelson and Merzlyak (1996) verified that even a small increase in the chlorophyll content of green leaves lead to a significant decrease in the reflectance, so it can be possible that in the visible bands the significant differences between DHFR values could be associated to differences on the chlorophyll content (differences). Anyway, the significant differences in DHFR were quite important even at laboratory investigation since they are at least (because at least they are) indicatives that orbital data from visible and NIR spectral regions could also be explored in mangrove species identification.

The optical analysis of leaf epidermis showed that
Rhizophora has far more chloroplasts than the other species although the total amount of chlorophyll was not measured in this study. Photosynthetic and chemical components probably are responsible for the lowest brightness of Rhizophora mangle in the visible bands. The reflectance of the leaf water content is measured by the wavelengths of 1.45-1.93 $\mu \mathrm{m}$ (Thomas et al. 1971) and it was not discussed in this paper.

In spite of Ponzoni and Gonçalves (1999) having recommended the usage of larger spectral bands, it should be interesting to consider the possibility to obtain orbital hyperspectral (Hyperion data, for instance) from mangrove areas. Considering the greater amount of mangroves spectra that could be extracted from the hyperspectral images, statistical procedures like those utilized by Galvão et al. (2005), for example, could be applied in the entire spectral range data in order to identify differences or similarities between mangroves canopies.

\section{CONCLUSIONS}

The spectral identification of the 4 mangrove species was possible. All mangrove species were distinguished in band 1. In the visible bands 2 and 3 the spectra of $A$. germinans and L. racemosa were confused and otherwise in the NIR band 4 the spectra of $C$. erectus and $R$. mangle would be confused.

Considering the mangrove species in this study Conocarpus erectus had the highest reflectance and Rhizophora mangle had the lowest in the visible bands, while in the NIR region the leaf reflectance of Avicennia germinans was higher and Laguncularia racemosa was lower than both of the other 2 species.

Disregarding the aspects related to the architecture of canopies dominated by these species one should expect when using airborne or orbital data high reflectance values in canopies of $C$. erectus in the visible bands. The contrary should be expected for $R$. mangle canopies. In the visible bands canopies of $A$. germinans and $L$. racemosa would be confounded. In the NIR region however canopies of $A$. germinans are expected to be brighter while $L$. racemosa should present darker canopies. Both $R$. mangle and L. racemosa should be confounded in the NIR region. 


\section{ACKNOWLEDGMENTS}

The authors wish to acknowledge gratefully the unfailing support received from City Hall of Bacuri Municipality, Secretaria do Meio Ambiente do Estado do Maranhão (SEMA), Instituto Nacional de Pesquisas Espaciais (INPE), Conselho Nacional de Desenvolvimento Científico e Tecnológico (CNPq), Universidade Federal do Maranhão (UFMA), Universidade Federal Fluminense (UFF) and from all collaborators whose valuable efforts were essential to this work.

\section{RESUMO}

Comunidades de manguezais são sistemas tropicais que apresentam poucas espécies constituintes em relação às florestas tropicais úmidas, especialmente na América Latina e apresentam arquitetura simples, freqüentemente com a falta de vários estratos encontrados em outros ecossistemas florestais. A identificação de manguezais mediante a observação de dados orbitais não é uma tarefa muito complicada, porém um desafio interessante seria sua diferenciação mediante a identificação de espécies dominantes. O primeiro passo para essa identificação florística é a caracterização espectral de folhas isoladas. Folhas de quatro espécies arbóreas de manguezais foram caracterizadas espectralmente considerando o Fator de Reflectância Direcional-Hemisférico (FRDH) determinado através de medidas radiométricas realizadas com o uso de uma esfera integradora LICOR 1800, acoplada a um espectrorradiômetro SPECTRON SE-590. Na região do visível (0,45-0,69 $\mu \mathrm{m})$, o denominado mangue de folhas arredondadas de Canocarpus erectus foi o mais brilhante e o mangue vermelho de $R h i$ zophora mangle foi o mais escuro, em comparação com os dois demais manguezais estudados, que apresentaram valores de FRDH muito próximos entre si. O denominado mangue preto de Avicennia germinans pode ser distinguido do mangue branco de Laguncularia racemosa na região do Infravermelho Próximo $(0,76-0,90 \mu \mathrm{m})$ e nessa mesma região, os espectros de FRDH de $C$. erectus e de $R$. mangle foram muito similares entre si.

Palavras-chave: reflectância de folhas, manguezais, caracterização espectral de folhas.

\section{REFERENCES}

CARdoso PCS And Ponzoni FJ. 1996. Caracterização espectral de folhas extraídas de cinco diferentes espécies de vegetais. In: VIII SIMPÓSIO BRASILEIRO DE SENSORIAMENTO REMOTO, Salvador, BA.

Cintrón G And Schaeffer-Novelli Y. 1992. Ecology and management of New World mangroves. In: SEELIGER U (Ed), Coastal plant communities of Latin America. Academic Press, San Diego, p. 233-258.

Cintrón G AND SchaefFer-Novelli Y. 1983. Introduccion a la ecologia del manglar. Oficina Regional de Ciencia y Tecnologia da la Unesco para America Latina y el Caribe, ROSTLAC, Montevideo, Uruguay, 109 p.

Galvão LS, Formaggio AR AND Tisot DA. 2005. Discrimination of sugarcane varieties in Southeastern Brazil with EO-1 Hyperion data. Rem Sens Environ 94: 523 534.

Gates DM, Keegan HJ, Schleter JC And Weidner VR. 1965. Spectral Properties of plants. App Opt 4: 1120.

GAUSMAN HW. 1974. Leaf reflectance of near infrared. Photogram. Eng 40: 183-191.

Gitelson AA AND MerzlyaK MN. 1996. Signature analysis of leaf reflectance spectra: algorithm development for remote sensing of chlorophyll. J Pl Phys 148: 494-500.

HERZ R. 1985. Sensoriamento remoto, gerenciamento costeiro. Relatório de Pós-Doutorado, Direction Environement et Recherche Oceanique. Dero at Dero el, Centre de Brest.

Herz R. 1991. Manguezais do Brasil. São Paulo: Instituto Oceanográfico de São Paulo, 227 p.

HERZ R AND JASKOW A. 1985. Remote sensing of mangrove areas on the Brazilian Coast. Proceedings of the Coastal Zone 85, Baltimore, Maryland, USA.

KJERFVE B AND LACERDA LD DE. 1993. Mangroves of Brazil. Mangr Ecosys Tech Rep 2: 245-272.

KJerfye B, Perillo GM, Gardner LR, Rine JM, Dias GTM AND Mochel FR. 2002. Morphodynamics of muddy environments along the Atlantic coasts of North and South America. In: Muddy CoAsts of THE WORLD: Processes, DEPOSITS AND FUnCTIONS. $1^{\text {st }}$ ed., Amsterdam, Elsevier Science, p. 479-532.

Lacerda LD, Conde JE, Bacon PR, Alarcon C, D'Croz L, KJehrfve B, Polania J and Vannucci M. 1993. Mangrove ecosystems of Latin America and the Caribbean: a summary. In: LACERDA LD (Ed), Conservation and Sustainable Utilization of mangrove Forests in Latin America and Africa Regions. Part I - Latin America.Okinawa: ISME, Japan, p. 1-42.

LONG BG AND SKewES TD. 1996. A Technique for Mapping Mangroves with Landsat TM Satellite Data and 
Geographic Information System. Est, Coast Sh Sci 3: 373-381.

PIRES IO. 1986. Mapeamento dos manguezais do recôncavo da Baía de Guanabara, RJ, através de técnicas de sensoriamento remoto. São José dos Campos, Dissertação Mestrado em Sensoriamento Remoto e Aplicações, Instituto Nacional de Pesquisas Espaciais, 86 p.

PIres IO AND Herz R. 1987. Mapeamento e monitoramento dos manguezais da APA - Guapimirim, RJ, através de técnicas de sensoriamento remoto: sistemas de classificação. Anais do I Simpósio sobre Ecossistemas da Costa Sul e Sudeste Brasileira: Síntese dos Conhecimentos. Academia de Ciências do Estado de São Paulo, ACIES, São Paulo, p. 298-303.

Pires IO AND Herz R. 1988. Determinação de índice de vegetação e realçamento de imagens em áreas de manguezais. Anais do V Simpósio Brasileiro de Sensoriamento Remoto, Instituto Nacional de Pesquisas Espaciais INPE, São José dos Campos, p. 19-23.

PonZONi FJ. 2001. Comportamento Espectral da Vegetação. In: Meneses PR And Madeira J DA S (Eds). Sensoriamento Remoto: reflectância de alvos naturais. UnB Editora, Brasília, DF, 262 p.

Ponzoni FJ AND GonÇALVES JLM. 1999. Spectral features associated with nitrogen, phosphorous and potassium deficiencies in Eucalyptus saligna seedling leaves. Int J Rem Sens 20: 2249-2264.

Ponzoni FJ, Sousa CL And Cardoso PCS. 1997. Alterações na reflectância espectral de folhas isoladas em função do horário diurno, Instituto Nacional de Pesquisas Espaciais INPE, São José dos Campos, Brasil. INPE6135-NTC-329.

RAMSEY EW AND JENSEN JR. 1996. Remote sensing of mangrove wetlands relating canopy spectra to site-specific data. Photogram Eng Rem Sens 62: 939-948.

ReBelo-Mochel F. 1993. Mangroves of Maranhão State, North Brazil. In: LACERDA LD AND FIELD CD (Eds), Mangrove Ecosystems Proceedings, Okinawa: ISME, Japan 1: 14.

Rebelo-Mochel F. 1995. Manguezais do Maranhão: proteção e desenvolvimento. Manguezais frontais da costa do Pará-Maranhão: razões da proteção integrada. Anais da $47^{\text {a }}$ Reunião da Sociedade Brasileira para o Progresso da Ciência, São Luis, MA, Brasil 1: 15-16.
Rebelo-Mochel F, Macedo LAA, Rego MMC, CUTRIM MV, KowARICK MA, RODRIGUES MS AND FERREIRA-CORREIA MM. 1991. In: DiagnÓstico DOS PRINCIPAIS PROBLEMAS AMBIENTAIS DO ESTADO Do MARANHÃo. IBAMA/SEMATUR, São Luís, MA, Brasil.

RoBERTSON AI. 1992. Concluding remarks: research and mangrove conservation. Coast and Est Stud 41: 225-249.

SANT'Anna EM AND Whately MH. 1981. Distribuição dos manguezais do Brasil. Rev Bras de Geog 43: 47-63.

SAnTOS MCFV DOS. 1986. Considerações sobre a ocorrência de Rhizophora harrisonii Leechman e Rhizophora racemosa G.F.W. Meyer, no litoral do Estado do Maranhão, Brasil. Boletim do Laboratório de Hidrobiologia 7 : 71-91.

SCHAEFFER-Novelli Y AND Cintrón G. 1986. Guia para estudos em áreas de manguezal. Estrutura, Função e Flora. Caribb Ecol Res, Porto Rico, 150p + 3ap.

Silva CA, LACERDA LD AND Rezende CE. 1990. Metals reservoir in a red mangrove forest. Biotropica 22: 339345.

Sousa CL, Ribeiro MC And Ponzoni FJ. 1996. Influência do tempo e do armazenamento na reflectância espectral de folhas de Eucalyptus grandis "ex situ". Rev Árvore 19: 466-478.

STACE CA. 1965. The significance of the leaf epidermis in the taxonomy of the Combretaceae. I. A general view of tribal, generic and specific characters. J of Linn Soc Bot 59: $229-252$.

Thomas JR, NAmken LN, Oerther GF AND Brown RG. 1971. Estimating leaf water content by reflectance measurements. Agron J 63: 845-848.

TomLinson PB. 1986. The Botany of Mangroves. Cambridge University Press, London.

TWILLEY RR. 1985. An Analysis of mangrove forests along the Gambia River estuary: implications for the management of estuarine resources. Report $\mathrm{N}^{\circ} 6$, Great Lakes and Marine Waters Center International Programs, University of Michigan, USA. 